\title{
VÝKON PRÁV DUŠEVNÉHO VLASTNÍCTVA AKO ZNEUŽITIE DOMINANTNÉHO POSTAVENIA NA TRHU - ROZSUDOK HUAWEI V ZTE
}

\author{
KATARÍNA KESSELOVÁ ${ }^{1}$
}

\begin{abstract}
ABSTRAKT
Príspevok poskytuje stručný prehl'ad vplyvu sútažného práva na duševné vlastníctvo, predovšetkým na licencovanie predmetov priemyselného práva, ktoré sú súčastou technického štandardu. Opísaný je postup tvorby štandardov a tzv. FRAND záväzky. Príspevok sa venuje okolnostiam, za ktorých držitel práva duševného vlastníctva nie je oprávnený uplatnit’ zdržovací nárok voči nelicencovanému používatel'ovi. Následne popisuje, ako sa princíp „osobitných okolností " odlišne interpretoval v judikatúre ESD (Magill, IMS Health), postupe Európskej komisie (Microsoft, Samsung) a rozsudku SDEÚ vo veci Huawei v ZTE. V závere konštatujeme, že základné právo majitel'a patentu nevyhnutného pre normu (práva vylúčit’ ostatných) môže byt’ obmedzené na základe článku 102 ZFEÚ $v$ dôsledku legitímnych očakávaní vytvorených u tretích strán ochotných rokovat’o licenčných podmienkach.
\end{abstract}

\section{KLÚČOVÉ SLOVÁ}

Patent nevyhnutný pre normu, zneužitie dominantného postavenia, predbežné opatrenie, stanovenie štandardov, licenčné poplatky, hospodárska sútaž

\footnotetext{
1 JUDr. Mgr. Katarína Kesselová je absolventkou Právnickej fakulty Univerzity P. J. Šafárika v Košiciach a Prešovskej univerzity v Prešove. V súčasnosti pôsobí ako advokátska koncipientka v Košiciach. Kontaktný e-mail je k.kessel@protonmail.ch.
} 


\begin{abstract}
The paper provides a brief overview of the antitrust issues involving intellectual property, particularly regarding licensing technology essential to a standard. We describe main features of standard-setting process and the so-called FRAND commitments. The paper discusses the circumstances under which an IP right holder is not entitled to seek injunctive relief against an unlicensed implementer. Next, it observes that the application of the "exceptional circumstances" principle led to different interpretations in European case-law (Magill, IMS Health), European Commission's approach (Microsoft, Samsung) and judgment of the CJEU in Huawei $v$ ZTE. We conclude that the fundamental right of an essential patent holder (the right to exclude), could be subject to limitations under Article 102 TFEU due to legitimate expectations created among willing licensees.
\end{abstract}

\title{
KEYWORDS
}

Standard Essential Patent, Abuse of a Dominant Position, Injunction, Standardsetting, Royalties, Competition

\section{1. ÚVOD}

Ochrana práv duševného vlastníctva a právo hospodárskej sútaže sledujú spoločný ciel' - podporu tvorby a inovácie. Aj tu platí, že ak dvaja robia to isté, nie je to to isté. Regulácia hospodárskej sútaže má bránit dominantným podnikom v zneužívaní ich silnej pozície na trhu. Priemyselné práva naopak poskytujú pôvodcom výlučné (hoc časovo obmedzené) právo monopolného využívania výsledkov ich tvorivej duševnej činnosti. Už definovanie základných prístupov týchto dvoch odvetví práva („bránenie zneužívaniu dominantného postavenia“ a „garantovanie výlučného práva“) implikuje istý konflikt a neistotu u dotknutých subjektov práv.

V článku uvedieme prípady stretu uvedených právnych noriem a popíšeme závery, ktorými sa súdna prax snaží dosiahnut žiaducu konzistenciu právneho poriadku. Ide najmä o stanovenie podmienok, za ktorých môže sútažné právo zasiahnut do základného oprávnenia držitel’a práva z du- 
ševného vlastníctva, a to práva na výlučné využívanie vynálezu. ${ }^{2}$ Zameriame sa na primárne a sekundárne právo EÚ a judikatúru Súdneho dvora Európskej únie ${ }^{3}$ predovšetkým v sektore vývoja smartfónov.

Príspevkom sa taktiež snažíme poukázat na to, že hoci je samou podstatou patentu výlučné právo ${ }^{4}$ majitela k vynálezu, pre technologický rozvoj je rovnako dôležité aj opačné smerovanie - zdielanie patentových portfólií. Aj tí najväčší konkurenti totiž majú záujem na kompatibilite svojich výrobkov, čo je na prospech nielen jednotlivým spotrebitel'om, ale v konečnom dôsledku aj trhovej sútaži, ktorá sa nachádza $\mathrm{v}$ pomyselnom strede Vennovho diagramu týchto dvoch právnych odvetví.

\section{KEDY JE ODMIETNUTIE POSKYTNUTIA LICENCIE ZNEUŽITÍM DOMINANTNÉHO POSTAVENIA?}

Majitel' patentu má výhradné právo rozhodnút o udelení licencie na používanie svojho duševného vlastníctva a právo bránit tým, ktorým súhlas neudelil $\mathrm{v}$ jeho využívaní. ${ }^{5} \mathrm{~V}$ prípade majitela patentu s dominantným postavením na trhu by takéto konanie, inak súladné s právnou úpravou, mohlo byt posúdené ako zneužitie dominantného postavenia podla čl. 102 Zmluvy o Európskej únii a Zmluvy o fungovaní Európskej únie ${ }^{6}$ (d’alej ako „ZFEÚ“). Je potrebné dodat, že samotné dominantné postavenie (existencia výlučného práva majitel’a patentu per se) nie je protisútažné. Problematické je až

2 CZAPRACKA, Katarzyna. Intellectual property and the limits of antitrust: a comparative study of US and EU approaches. Cheltenham: Edward Elgar, 2009. ISBN 9781847209252. s. 38.

3 Súdny dvor EÚ sa venoval hladaniu náležitej rovnováhy medzi ochranou nositelov autorských práv a ochranou slobody podnikania napr. v rozsudku tretej komory Súdneho dvora zo dňa 24. novembra 2011 vo veci Scarlet Extended SA v Société belge des auteurs, compositeurs et éditeurs SCRL (SABAM) C-70/10.

4 Bez súhlasu majitel’a patentu nikto nesmie vyrábat', využívat', používat', ponúkat alebo uvádzat na trh, alebo na tento účel skladovat či dovážat výrobok, ktorý je predmetom patentu. Ďalej pozri § 15 zákona č. 435/2001 Z. z. o patentoch, dodatkových ochranných osvedčeniach a o zmene a doplnení niektorých zákonov (patentový zákon).

5 Smernica Európskeho parlamentu a Rady 2004/48/ES z 29. apríla 2004 o vymožitel'nosti práv duševného vlastníctva (Ú. v. EÚ L 157, s. 45; Mim. vyd. 17/002, s. 32).

6 „Akékolvek zneužívanie dominantného postavenia na vnútornom trhu či jeho podstatnej časti jedným alebo viacerými podnikatelmi sa zakazuje ako nezlučitel'né $s$ vnútorným trhom, ak sa tým môže ovplyvnit obchod medzi členskými štátmi." Článok 102 ZFEÚ d’alej okrem generálnej klauzuly uvádza demonštratívne príklady zneužívania dominantného postavenia na trhu. 
jeho zneužitie. Teóriu „osobitných okolností“, za splnenia ktorých je odmietnutie poskytnutia licencie zneužitím dominantného postavenia, použil Súdny dvor v roku 1995 v prípade Magill ${ }^{7}$. Súd poskytol návod na vyváženie práv duševného vlastníctva ( $\mathrm{v}$ danom prípade práva autorského) a všeobecného záujmu na ochrane hospodárskej sútaže.

\section{MAGILL}

Írska spoločnost Magill zamýšlala vydávat prehl'ad všetkých televíznych programov $\mathrm{v}$ danej dobe $\mathrm{v}$ krajine dostupných. Vysielatelia, ktorí zverejňovali program svojich vlastných staníc, jej odmietli poskytnút potrebné údaje a argumentovali, že informácie o programe sú predmetom autorského práva. Je vhodné podotknút, že obsahom televízneho programu sú informácie, ktoré väčšina právnych poriadkov nepovažuje za predmet autorského práva. Avšak common law jurisdikcia, z ktorej pochádzali vysielatelia v prípade Magill, priznávala autorskoprávnu ochranu aj funkčnému a utilitaristickému obsahu, ${ }^{8}$ ako je prehl’ad TV vysielania. Súdny dvor skonštatoval, že vzhl'adom na absenciu komunitárnej harmonizácie v tejto oblasti, musí byt akceptované autorské právo členského štátu, ktoré poskytuje ochranu aj TV prehl'adom.

Európska komisia nariadila vysielatel’om poskytnút spoločnosti Magill požadované informácie o TV vysielaní. Súdny dvor rozhodnutie Komisie potvrdil. Uviedol, že v tomto prípade ide o „osobité okolnosti,“ pretože informácie o programe boli nevyhnutné na vytvorenie TV prehl’adu, o ktorý mali spotrebitelia záujem. Odmietnutím poskytnutia licencie vysielatelia znemožnili vytvorenie nového produktu a monopolizovali sekundárny (nadväzujúci) trh. ${ }^{9}$

Okolnosti, ktoré súd považoval za hodné zretel’a pri posudzovaní, či dochádza $\mathrm{k}$ zneužitiu dominantného postavenia, možno zhrnút nasledovne: (1) neexistuje ani potenciálny substitút $\mathrm{k}$ chránenému predmetu duševného

Rozsudok Súdneho dvora Európskych spoločenstiev zo dňa 6. 4. 1995 vo veci Radio Telefis Eireann (RTE) a Independent Television Publications Ltd (ITP) $v$ Commission of the European Communities. (spojené konania C-241/91 P and C-242/91 P).

8 STAMATOUDI, A. Irini. Copyright and multimedia products: a comparative analysis. Cambridge: Cambridge University Press, 2002. ISBN 0521808197. s. 88. 
vlastníctva a jeho použitie je v hospodárskej sútaži nevyhnutné, (2) žiadatel' o licenciu má zámer poskytovat výrobok alebo službu, ktorú majitel' práva duševného vlastníctva neposkytuje, a existuje potenciálny záujem o tento produkt alebo službu zo strany spotrebitelov, (3) neposkytnutie licencie by vylúčilo sútaž na sekundárnom (nadväzujúcom) trhu, (4) odmietnutie poskytnutia licencie nie je z objektívnych dôvodov ospravedlnitel'né. $^{10}$

Otázka okolností, za ktorých je možné považovat’ odmietnutie poskytnutia licencie zo strany dominantného držitel’a práva duševného vlastníctva za zneužitie jeho postavenia, bola následne predmetom rozhodnutia vo veci IMS Health ${ }^{11}$ (2004) a taktiež v prípade Microsoft Corp. (2012), ktorý popíšeme bližšie.

\section{MICROSOFT CORP.}

Európska komisia v roku 2004 prijala rozhodnutie, ${ }^{12} \mathrm{v}$ ktorom konštatovala, že spoločnost’ Microsoft zneužila dominantné postavenie na trhu s operačnými systémami. Spoločnost’ odmietla poskytnút softvérové protokoly konkurentom, ktoré by im umožnili vyvíjat’ a distribuovat̉ vlastné produkty na trhu operačných systémov pre servery pracovnej skupiny. Komisia nariadila spoločnosti sprístupnit informácie potrebné na prepojenie s Microsoft Windows a povolit ich používanie za primeraných a nediskriminačných podmienok. V roku 2008 Komisia skonštatovala, že túto povinnost’ Microsoft nesplnil a uložila spoločnosti pokutu vo výške 899 mil. eur.

9 Trh v d’alšej fáze výrobného/distribučného retazca, napríklad distribúcia a predaj motorových vozidiel, je dolný (následný) trh pre výrobu motorových vozidiel. Pozri EURÓPSKA KOMISIA: Slovník termínov používaných v politike hospodárskej sútaže EÚ. [online] 2008. [cit. 30. 9. 2017] Dostupné na: http:// wwwold.justice.sk/dwn/17/slovnik/slovnik_terminov_HS.rtf

10 AHLBORN, Christian, EVANS, S. David a PADILLA, A. Jorge. The Logic \& Limits of the "Exceptional Circumstances Test" in Magill and IMS Health. In: Fordham International Law Journal. 2004, Vol. 28.

11 Rozsudok Súdneho dvora Európskych spoločenstiev zo dňa 29. 4. 2004 vo veci IMS Health GmbH \& Co. OHG (Case C-418/01).

12 Rozhodnutie 2007/53/ES, ktoré sa vztahuje na konanie podla článku 82 [ES] a článku 54 Dohody o EHP vedené proti spoločnosti Microsoft Corp. (vec COMP/C-3/37.792 Microsoft) (Ú. v. EÚ L 32, 2007, s. 23). 
Microsoft bol prvou spoločnostou v histórii politiky hospodárskej sútaže v EÚ, ktorej bola uložená pokuta za nedodržanie predchádzajúceho rozhodnutia Komisie. ${ }^{13}$

Microsoft podal na Všeobecnom súde návrh na zrušenie tohto rozhodnutia, event. na zrušenie penále alebo zníženie jeho výšky. Všeobecný súd v rozsudku Microsoft Corp. proti Európskej komisii ${ }^{14}$ potvrdil podstatu rozhodnutia Komisie o uložení penále, ale znížil výšku na 860 miliónov eur.

Všeobecný súd (s poukazom na rozsudok vo veci IMS Health) uviedol, že na to, aby bolo možné kvalifikovat' odmietnutie zo strany nositel'a autorského práva, poskytnút prístup k výrobku alebo k službe nevyhnutnej na výkon danej činnosti ako zneužitie, stačí, aby boli splnené tri kumulatívne podmienky, a to že toto odmietnutie je (i) prekážkou vytvorenia nového produktu, po ktorom existuje potenciálny dopyt spotrebitel’ov, že (ii) odmietnutie nie je odôvodnené a (iii) je spôsobilé vylúčit akúkolvek hospodársku sútaž na odvodenom trhu. ${ }^{15}$

\section{OSOBITNÉ OKOLNOSTI}

Odmietnutie poskytnutia licencie môže byt zneužitím dominantného postavenia v zmysle článku 102 ZFEÚ len v prípade osobitných okolností. Takýto bol záver Súdneho dvora v prípade Magill, kde autorské právo vysielatela k prehl’adu programu vylučovalo, aby iná osoba mohla vydávat komplexný prehl'ad dostupných TV programov, pričom neexistoval žiadny substitút k požadovanému predmetu autorského práva. Ak je substitút možný, ${ }^{16}$ do exkluzivity práv nositela by sa nemalo zasahovat.

Osobitnou je aj situácia, ak právo k duševnému vlastníctvu umožňuje majitel'ovi rozšírit svoju dominantnú pozíciu z jedného trhu na iný. Rozširovanie dominantného postavenia neposkytnutím informácií potrebných pre interopearabilitu môže byt rovnako zneužitím dominantného posta-

${ }^{13}$ EURÓPSKA KOMISIA: Správa o politike hospodárskej sútaže za rok 2008. [online] 2009. Dostupné na: http://europa.eu/rapid/press-release_IP-09-1241_sk.pdf

14 Rozsudok Všeobecného súdu (druhá komora) z 27. 6. 2012 vo veci Microsoft Corp. proti Európskej komisii. (T-167/08). ECLI:EU:T:2012:323.

15 Bod 139 rozsudku vo veci Microsoft Corp. proti Európskej komisii (T-167/08).

16 Tzv. „inventing around a patent“. 
venia. ${ }^{17} \mathrm{~V}$ prípade, že je využitie predmetu práva duševného vlastníctva nevyhnutné na to, aby konkurent vstúpil na iný alebo súvisiaci trh, odmietnutie poskytnutia licencie by malo byt považované porušenie čl. 102 ZFEÚ. ${ }^{18}$ Ide najmä o situácie, ak je právom chránená technológia trhovým štandardom.

\section{6. ŠTANDARDIZÁCIA A „PATENTY NEVYHNUTNÉ PRE NORMU“}

Ako sa určitá technológia $\mathrm{v}$ oblasti informačno-komunikačných technológií stane štandardom? Môže sa prirodzene rozšírit do tej miery, že vytvorí tzv. de facto štandard, ako v prípade Portable Document Format („PDF“). Formálny proces stanovenia technických noriem sa odohráva na pôde štandardizačných organizácií, akými sú Európsky telekomunikačný štandardizačný inštitút ${ }^{19}$ („ETSI”) alebo Inštitút Elektrických a Elektronických Inžinierov $^{20}$ („IEEE”). K štandardom stanoveným v rámci týchto organizácii patrí: technológia Bluetooth, bezdrôtové širokopásmové technológie (WiFi), technológia na kompresiu videa (H.264), telekomunikačné štandardy (4G LTE), Universal Serial Bus („USB“), Hypertext Transfer Protocol („HTTP").

Členmi štandardizačných organizácií sú zástupcovia daného technického odvetvia. Stanovenie štandardu je obvykle podmienené využitím značného počtu patentov vlastnených týmito členmi. Ak je zahrnutie niektorého patentu nevyhnutné na dosiahnutie priemyselného štandardu, označuje sa ako „patent nevyhnutný pre normu“ („standard-essential patent" alebo skrátene „SEP“).

V prípade „bežného“, nie SEP patentu je pre druhého výrobcu zvyčajne možné navrhnút vlastné technické riešenie iným spôsobom, bez využitia

\footnotetext{
${ }^{17}$ EURÓPSKA KOMISIA: DG Competition discussion paper on the application of Article 82 of the Treaty to exclusionary abuses. [online] 2005. Dostupné na: http://ec.europa.eu/ competition/antitrust/art82/discpaper2005.pdf

18 THE MAX PLANCK INSTITUTE FOR INTELLECTUAL PROPERTY, COMPETITION AND TAX LAW: Comments of the Max Planck Institute for Intellectual Property, Competition and Tax Law (Munich) on the DG Competition discussion paper of December 2005 on the application of Article 82 of the EC Treaty to exclusionary abuses [online] 2006. [cit. 30. 9. 2017] Dostupné na: http://ec.europa.eu/competition/antitrust/art82/047.pdf

19 European Telecommunications Standards Institute.

${ }^{20}$ Institute of Electrical and Electronics Engineers.
} 
technológie chránenej patentom, pri súčasnom zachovaní klúčovej vlastnosti technológie. Avšak v prípade „patentu nevyhnutného pre normu“ výrobca nemá inú možnost̉ ako pri vlastnom technickom riešení využit duševné vlastníctvo inej osoby, pokial má záujem vyrobit zariadenie spĺňajúce technickú normu, napr. smartfón technológiu 4G LTE.

Interné pravidlá štandardizačných organizácií vyžadujú od členov, ktorí sa podielajú na procese stanovenia štandardu, aby včas informovali o svojich relevantných patentoch a patentových prihláškach. Zároveň sa od člena organizácie požaduje, aby sa vo forme vyhlásenia zaviazal poskytovat svoje práva vyplývajúce zo SEP patentu za spravodlivých, primeraných a nediskriminačných podmienok - označované akronymom FRAND (fair, reasonable, and nondiscriminatory) ostatným členom štandardizačnej organizácie alebo niekedy aj tretím osobám. $\mathrm{V}$ opačnom prípade by majitel' patentu zahrnutého $\mathrm{v}$ štandarde mohol podmieňovat prístup záujemcov o licenciu k danému SEP zaplatením takých vysokých licenčných poplatkov, že by im využívanie štandardizovanej technológie prakticky znemožnil. V spore Microsoft Corp. $v$ Motorola, $\operatorname{Inc}^{21}$ napríklad Motorola požadovala za implementáciu jej SEP patentov (H.264 ${ }^{22}$ a $802.11^{23}$ ) na konzolách Xbox a operačnom systéme Windows licenčný poplatok vo výške 6 až 8 dolárov za koncové zariadenie, pričom súd dospel k záveru, že FRAND licencii zodpovedá výška 0.00555 dolára za $\mathrm{H} .264$ na zariadenie a 0.03471 dolára za 802.11 na zariadenie. Od výrobcu teda majitel' SEP patentu požadoval viac ako 100-násobok súdom určenej hodnoty licencie.

Právny charakter vyhlásenia FRAND sa v teórii aj praxi posudzuje rôzne. Prevláda názor, že vyhlásenie o poskytnutí licencie za podmienok FRAND nie je samo osebe licenciou, iba zaväzuje k súkromnoprávnemu rokovaniu bez intervencie štandardizačnej organizácie. Niektorí autori považujú FRAND vyhlásenie za záväzok, ktorého porušenie môže znamenat̉ zodpo-

\footnotetext{
${ }^{21}$ Rozsudok US District Court Western District of Washington at Seattle zo dňa 25. 4. 2013 vo veci Microsoft Corp. $v$ Motorola, Inc., C10-1823JLR.

${ }^{22}$ H.264 video compression standard.

${ }^{23} 802.11$ (Wi-Fi) wireless local area networking standard.
} 
vednoste podla práva hospodárskej sútaže,${ }^{24}$ iní priamo za zmluvu, ${ }^{25}$ ktorú držitel' SEP dobrovol’ne uzatvoril so štandardizačnou organizáciou. Nemecké súdy však takéto argumenty odmietli. Súd v Mannheime napríklad opakovane uviedol, že FRAND vyhlásenia nezakladajú záväzok, pretože nie sú dostatočne určité a taktiež absentuje vôla uzatvorit záväzkový vztah. ${ }^{26}$ High court of Justice v prípade Unwired Planet $v$ Huawei ${ }^{27}$ povahu FRAND vyhlásenia posúdil nasledovne: vnútorné pravidlá štandardizačnej organizácie $\mathrm{ETSI}^{28}$ sa riadia francúzskym právom, rovnako ako samotné FRAND vyhlásenie. Na základe vyjadrenia znalcov francúzskeho práva a princípu „stipulation pour autrui“ (vol'ne preložené ako zmluva v prospech tretej osoby) rozhodol, že FRAND vyhlásenie držitel’a SEP vytvára práva v prospech tretích osôb. Domnelý narušitel’ práv k SEP je preto spôsobilý domáhat sa splnenia tohto vyhlásenia držitel’om SEP.

S ciel’om predchádzat situáciám nazývaným patent hold-up, ked’ vlastník SEP požaduje neprimerané licenčné poplatky pod hrozbou zdržovacej žaloby, štandardizačné organizácie vyžadujú, aby majitelia pre štandard nevyhnutých patentov tieto vopred identifikovali vo svojom patentovom portfóliu a zároveň, aby sa zaviazali $\mathrm{k}$ poskytnutiu licencie za podmienok FRAND. Je možný aj opačný scenár tzv. patent hold out, ked’ narušitel’ práv využíva svoju ekonomickú silu a vyhýba sa zaplateniu akejkolvek odmeny, neprimerane nałahuje rokovania o výške licencie s cielom prinútit držitela pa-

24 PETIT, Nicolas. EU Competition Law Analysis of FRAND Disputes in The Cambridge Handbook of Technical Standardization Law, Jorge L. Contreras, ed., Cambridge University Press, Forthcoming 2017. s. 2.

25 BROOKS Roger G. \& GERADIN Damien. Taking Contracts Seriously: The Meaning of the Voluntary Commitment to Licence Essential Patents on "Fair and Reasonable" Terms. [online] 2010. [cit. 30. 9. 2017] Dostupné na: https://www.cravath.com/files/Uploads/Documents/ Publications/3233990_1.pdf

26 MAUME, Philipp. Huawei ./. ZTE, or, how the CJEU closed the Orange Book. In Queen Mary Journal of Intellectual Property. Online ISSN 20459815 [online] 2016. [cit. 30. 9. 2017] Dostupné na: https://www.elgaronline.com/view/journals/qmjip/62/qmjip.2016.02.04.xml

27 Rozsudok High Court of Justice zo dňa 5. 4. 2017 vo veci Unwired Planet International Ltd v Huawei Technologies Co. Ltd and Huawei Technologies (UK) Co. Ltd (EWHC 711 (Pat).

28 EUROPEAN TELECOMMUNICATIONS STANDARDS INSTITUTE: ETSI Intellectual Property Rights Policy. [online] 2017. [cit. 30. 9. 2017] Dostupné na http://www.etsi.org/images/files/IPR/etsi-ipr-policy.pdf 
tentu akceptovat nižšiu než primeranú výšku licencie. Menší a ekonomicky slabší držitelia patentu môžu preferovat’ nevýhodné licenčné podmienky pred časovo a finančne nákladným sporom o porušení práv k patentu.

FRAND záväzok predstavuje istú protihodnotu či quid pro quo k patentu, ktorý sa má stał súčastou štandardu. Majitel SEP patentu tým zvolí pred vyššou cenou licencie na jedno zariadenie síce cenu nižšiu, avšak s vedomím, že jeho patent bude používaný na ovela väčšom počte koncových zariadení.

\section{LICENČNÉ SPORY TÝKAJÚCE SA PATENTOV NEVYHNUTNÝCH PRE NORMU}

V typickom spore v tejto oblasti vlastník SEP uplatňuje prostriedky právnej ochrany voči osobe, ktorá štandardizovanú technológiu využíva bez potrebnej licencie. Vlastník SEP podá návrh na vydanie súdneho opatrenia s ciel’om bud' zabránit konkurentovi používat patenty nevyhnutné pre normu vo svojich výrobkoch, alebo uložit mu povinnost̉ stiahnut z trhu zariadenia, ktoré SEP už využívajú.

Žalovaná strana, nelicencovaný používatel' patentu nevyhnutného pre normu, na obranu proti žalobe môže namietat zneužitie dominantného postavenia majitelom SEP podla článku 102 ZFEÚ. Druhou možnostou žalovanej strany je obrana pomocou „FRAND námietky“, ked’ sa snaží preukázat, že bola ochotná zaplatit licenciu za použitie SEP, avšak majitel patentu nepristúpil na dohodu za FRAND podmienok. Nie je prekvapujúce, že vlastník SEP a záujemca o licenciu majú často odlišnú predstavu o „spravodlivej, primeranej a nediskriminačnej“ výške licencie. (Štandardizačná organizácia sa na týchto sporoch o vyčíslení FRAND licencie nezúčastňuje.)

Druhý možný scenár sporu z patentu nevyhnutného pre normu sa začína na podnet nelicencovaného používatela SEP, ktorý pred Európskou komisiou alebo národným protimonopolným úradom iniciuje konanie o zneužívaní dominantného postavenia majitel'om SEP patentu. Takúto stažnost̉ podali v roku 2005 Ericsson, Nokia, Panasonic a d'alší proti spoločnosti Qualcomm, v ktorej tvrdili, že výška licencie, ktorú Qualcomm požadoval za 
svoje patenty a ktoré sa stali súčastou štandardu 3G, boli neprimerane vysoké a že spoločnost’ sa snažila vylúčit konkurenčných výrobcov čipov $\mathrm{z}$ trhu. Po dvoch rokoch prieskumu Komisia vyšetrovanie ukončila, pretože oznamovatelia postupne svoje žiadosti stiahli. ${ }^{29}$

\section{SAMSUNG ELECTRONICS: NEDODRŽANIE ZÁVÄZKU FRAND}

Právo majitel'a patentu nevyhnutného pre normu začat konanie o vydanie zdržovacích žalôb proti konkurentovi predstavuje „negociačnú zbraň“, umožňujúcu získat neprimerane vysoké licenčné poplatky od údajných narušitel’ov, a to aj za predpokladu, že vlastník prijal FRAND záväzok. Na druhej strane, ak sa majitel'om SEP odoprie právo na súdnu ochranu prostredníctvom súdnych zákazov, prípadných konkurentov to môže motivovat' natahovat' rokovania o odplate za SEP bez akejkol'vek obavy zo žaloby zo strany majitela. ${ }^{30}$

V decembri 2012 Európska komisia ${ }^{31}$ oznámila spoločnosti Samsung Electronics námietky, ${ }^{32}$ ktoré predstavujú formálny krok pri vyšetrovaní Komisie $\mathrm{v}$ súvislosti s podozreniami $\mathrm{z}$ porušenia antitrustových pravidiel. ${ }^{33}$ Juhokórejský výrobca elektroniky inicioval vo viacerých členských štátoch konania o vydanie zdržovacích žalôb proti spoločnosti Apple z dôvodu porušenia patentov nevyhnutných pre štandard 3G UMTS. ${ }^{34}$ Podla Komisie

29 LUNDQVIST, Björn. Standardization under EU Competition Rules and US Antitrust Laws: The Rise and Limits of Self-Regulation. Cheltenham: Edward Elgar Publishing. 2014. ISBN 9781781954850. s. 310.

30 BROWN-SANFORD Christa \& FORD R. Bethany. Post-Huawei FRAND Licensing of StandardsEssential Patents. [online] 2017. Dostupné na: http://www.bakerbotts.com/ideas/publications/2016/06/ip-report-post-huawei-frand-licensing

31 EURÓPSKA KOMISIA: Tlačová správa zo dňa 21. 12. 2012: Antitrust: Commission sends Statement of Objections to Samsung on potential misuse of mobile phone standard-essential patents. [online] 2012. [cit. 30. 9. 2017] Dostupné na: http://europa.eu/rapid/press-release_IP-121448_en.htm

32 Statement of Objections.

${ }^{33}$ Komisia písomne informuje dotknuté strany o vznesených námietkach. Adresáti môžu preskúmat dokumenty vyšetrovacieho spisu Komisie, odpovedat písomne a požiadat o ústne vypočutie, počas ktorého môžu vyjadrit svoje pripomienky v danej veci pred zástupcami Komisie a vnútroštátnych orgánov na ochranu hospodárskej sútaže.

34 UMTS (Universal Mobile Telecommunications System) je technológia pre rýchly prenos dát sietou mobilného operátora. 
došlo k zneužitiu dominantného postavenia, pretože Samsung Electronics pred štandardizačnou organizáciou ETSI prijala záväzok poskytnút licenciu k svojim SEP (kl’účovým pre implementáciu štandardov tretej generácie mobilných telefónov) za FRAND podmienok a spoločnost̉ Apple sa javila ako ochotná rokovat o týchto licenčných podmienkach. Pokial' by nešlo o uvedené osobitné okolnosti, právo majitel'a patentu domáhat sa vydania súdneho zákazu proti nelicencovaným používatel’om, by Komisia nespochybňovala. $^{35}$

Samsung následne predložil Komisii návrh svojich záväzkov, ktorými chcel vznesené námietky urovnat. V roku 2014 Komisia prijala záväzok spoločnosti Samsung, ${ }^{36}$ že sa výrobca nebude počas piatich rokov domáhat’ súdnych zákazov v EEA na základe svojich SEP, týkajúcich sa smartfónov a tabletov proti spoločnostiam, ktoré budú súhlasit s licenčným rámcom. Ten predpokladá, že ak sa strany počas najviac 12-mesačného rokovacieho obdobia nedohodnú na licenčných podmienkach, každá sa môže v otázke určenia výšky licencie obrátit’ na súd, resp. po vzájomnej dohode na arbitra. Proti záujemcom o licenciu na využívanie SEP, ktorí sa do tohto licenčného rámca zapoja, nebude Samsung navrhovat’ vydanie súdnych zákazov.

\section{HUAWEI V ZTE ${ }^{37}$}

V roku 2015 sa Súdny dvor vyjadril k prejudiciálnej otázke, či majitel patentu nevyhnutného pre normu, ktorý vyjadril pred štandardizačnou organizáciou ochotu poskytnút licencie tretím osobám za FRAND podmienok, zneužíva svoje dominantné postavenie, ak voči porušovatel'ovi práv z daného patentu uplatňuje súdne nárok na zdržanie sa konania, hoci údajný porušovatel' deklaroval vôl'u rokovat’ o podmienkach takejto licencie.

35 Ibid 30.

${ }^{36}$ EURÓPSKA KOMISIA: Tlačová správa zo dňa 29. 4. 2014: Antitrust: Commission accepts legally binding commitments by Samsung Electronics on standard essential patent injunctions. [online] 2014. [cit. 30. 9. 2017] Dostupné na: http://europa.eu/rapid/press-release_IP-14490_en.htm

37 Rozsudok Súdneho dvora (piata komora) zo 16. 7. 2015 vo veci Huawei Technologies Co. Ltd/ZTE Corp., ZTE Deutschland GmbH. (Vec C-170/13). ECLI:EU:C:2015:477. 
Predmetom sporu bol európsky patent patriaci spoločnosti Huawei s názvom „metóda a zariadenie na vytvorenie synchronizačného signálu v spojovacom systéme,“38 ktorý bol zahrnutý do normy „Long Term Evolution.“ Spoločnost’ sa pritom pred štandardizačnou organizáciou ETSI zaviazala udelit tretím osobám licenciu za podmienok FRAND.

Spoločnost̉ ZTE Corp., ktorá uvádza na trh zariadenia vybavené softvérom, na ktorý sa vztahuje uvedená norma, a Huawei rokovali o podmienkach udelenia licencie $\mathrm{k}$ patentu, ale nedospeli k dohode. Huawei následne podala žalobu, v ktorej sa domáhala zdržania sa porušovania práv, poskytnutia účtovných údajov, stiahnutia výrobkov z trhu, ako aj poskytnutia náhrady škody. ${ }^{39}$ Vnútroštátny súd musel posúdité, či tým spoločnost̉ zneužíva svoje dominantné postavenie, čím porušuje článok 102 ZFEÚ.

Súdny dvor s poukazom na svoje predošlé rozhodnutia konštatoval, že výkon výlučného práva vyplývajúceho z práv duševného vlastníctva, a to práva podat žalobu pre porušenie práv, je súčastou výsad majitel'a patentu, takže výkon takého práva, aj ked’ ho uskutočňuje podnik s dominantným postavením, nemôže sám osebe predstavovat’ zneužitie tohto dominantného postavenia. ${ }^{40}$ Za nesporé súd taktiež považuje, že výkon výlučného práva vyplývajúceho z práv duševného vlastníctva, jeho majitel’om môže za výnimočných okolností viest' k zneužitiu v zmysle článku 102 ZFEÚ. ${ }^{41}$ Osobitost' sporu vo veci Huawei $v$ ZTE podl'a súdu spočíva jednak v tom, že predmetný patent je nevyhnutný pre normu vypracovanú organizáciou pre normalizáciu, pričom jej účinkom je, že každý konkurent, ktorý chce vyrábat? výrobky v súlade s normou, na ktorú sa uvedený patent vztahuje, musí tento patent používat. ${ }^{42}$ Druhou osobitnou okolnostou prípadu, je neodvolatel’ný záväzok majitel’a SEP prijatý pred štandardizačnou organizáciou a vyjadrujúci ochotu udelit' licencie za FRAND podmienok. ${ }^{43}$

\footnotetext{
38 Európsky patent s číslom EP 2090050 B 1.

39 Body 21 -27 rozsudku Huawei $v$ ZTE.

40 Bod 46 rozsudku Huawei $v$ ZTE.

${ }^{41}$ Bod 47 rozsudku Huawei $v$ ZTE.

42 Bod 49 rozsudku Huawei $v$ ZTE.

43 Bod 49 rozsudku Huawei $v$ ZTE.
} 
S ciel’om zabránit tomu, aby žaloba o zdržanie sa konania alebo smerujúca $\mathrm{k}$ uloženiu povinnosti stiahnut výrobky z trhu mohla byt považovaná za zneužitie v zmysle čl. 102 ZFEÚ, majitel SEP musí podla Súdneho dvora dodržat podmienky, ktorých účelom je zabezpečit spravodlivú rovnováhu medzi dotknutými záujmami.

Podla rozsudku je vlastník patentu nevyhnutného pre normu oprávnený dožadovat’ sa, aby súd uložil konkurentovi, ktorý vyrába alebo predáva výrobok porušujúci jeho SEP, stiahnut výrobky z trhu, resp. zdržat sa konania, až za predpokladu, že:

(1) Vlastník patentu nevyhnutného pre normu upozornil potenciálneho narušitel’a patentu na porušovanie svojich práv. Podla Súdneho dvora je to primerané vzhl'adom na vel'ký počet SEP a možnost', že narušitel' si porušenia SEP nie je vedomý.

(2) Ak potenciálny narušitel vyjadril vôlu uzatvorit licenčnú zmluvu, je na vlastníkovi patentu nevyhnutného pre normu predložit potenciálnemu narušitelovi konkrétnu písomnú ponuku licencie za podmienok FRAND;

(3) Narušitel nereagoval na predloženú ponuku v primeranej dobe a dostatočne starostlivým spôsobom.

Údajný porušovatel práv sa $\mathrm{v}$ prípade, že neprijme návrh, ktorý mu bol predložený, môže odvolávat na zneužívajúcu povahu žaloby o zdržanie sa konania alebo smerujúcej k uloženiu povinnosti stiahnut výrobky z trhu len v prípade, že majitelovi dotknutého SEP predloží v čo najkratšom čase a písomne konkrétny protinávrh zodpovedajúci podmienkam FRAND. ${ }^{44}$

Môžeme zhrnút, že vlastník SEP má notifikačnú a ponukovú povinnost'. Následne je na údajnom porušitel’ovi, aby sa v súlade s obchodnými zvyklostami daného odvetvia zaoberal týmto návrhom. Musí konat v dobrej viere, čo vylučuje používanie zdržovacích praktík. Ak porušitel' neakceptuje návrh vlastníka SEP, musí predložit svoju písomnú protiponuku, ktorá zodpovedá podmienkam FRAND, inak je majitel patentu nevyhnutného pre normu oprávnený iniciovat súdne konanie. Navyše, pokial' je protiponuka odmietnutá, narušitel' musí poskytnút majitel’ovi SEP primeranú zábezpeku, napr. bankovú záruku alebo iný depozit predbežnej sumy licenčných po-

\footnotetext{
${ }^{44}$ Bod 66 rozsudku Huawei $v$ ZTE.
} 
platkov za minulé aj budúce použitia predmetného SEP. Ak nebola dosiahnutá nijaká dohoda, strany sa môžu dohodnút, aby sumu licenčného poplatku určila tretia nezávislá osoba.

Súdny dvor dopíňa, že nemožno údajnému porušovatel'ovi práv vytýkat,, že súbežne s rokovaniami týkajúcimi sa udelenia licencií bud’ spochybní platnost týchto patentov a/alebo ich nevyhnutnoste pre normu, na ktorej sa podiel’ajú, a/alebo ich skutočné používanie, alebo si vyhradí možnost̉ tak urobit neskôr. ${ }^{45}$

Súdny dvor sa v odôvodnení Huawei v ZTE nezaoberal preukazovaním dominantného postavenia Huawei, pretože vnútroštátny súd existenciu dominantného postavenia nespochybnil. Generálny advokát ${ }^{46}$ však vo svojom stanovisku uvádza, že skutočnost', že podnik je majitel’om SEP, nutne neznamená, že má dominantné postavenie na trhu: „Hoci skutočnost', že každý, kto používa normu stanovenú organizáciou pre normalizáciu, musí nutne využívat' SEP, takže potrebuje licenciu od majitel'a tohto patentu, môže zakladat' vyvrátitel'nú domnienku o existencii dominantného postavenia majitel'a tohto patentu na trhu, domnievam sa, že túto domnienku musí byt’ možné vyvrátit konkrétnymi a podrobnými indíciami.“

Rozhodnutie vo veci Huawei $v$ ZTE nadväzuje na prípad IMS Health, v ktorom Súdny dvor konštatoval, že je zneužitím dominantného postavenia, ak sa právo duševného vlastníctva použije na zablokovanie prístupu $\mathrm{k}$ sekundárnemu (nadväzujúcemu) trhu. ${ }^{47} \mathrm{~V}$ prípade Huawei $v$ ZTE však Súdny dvor nespomína ako podmienku vytvorenie nového typu produktu alebo služby. Za osobitnú okolnost považuje to, že majitel' SEP vytvoril u tretích osôb legitímne očakávania, že im za „spravodlivých, primeraných a nediskriminačných" podmienok poskytne licenciu k patentu nevyhnutnému na dosiahnutie technického štandardu.

\footnotetext{
45 Bod 69 rozsudku Huawei $v$ ZTE.

46 Body 53-58 Návrhov generálneho advokáta Melchior Wathelet prednesené 20. 11. 2014, vo veci C-170/13 Huawei Technologies Co. Ltd proti ZTE Corp., ZTE Deutschland GmbH. ECLI:EU:C:2014:2391.

47 Ibid 25.
} 


\section{0. „POST-HUAWEI“ A OTVORENÉ OTÁZKY}

Rozhodnutie Huawei $v$ ZTE objasňuje majitel'ovi patentu nevyhnutného pre normu ako postupovat', aby sa v súdnom konaní vedenom proti porušitelovi práv ubránil námietke o zneužití dominantného postavenia. (Na druhej strane, údajný porušitel' sa nemôže dovolávat obrany prostredníctvom čl. 102 ZFEÚ, ak nesplnil svoje povinnosti opísané v tomto rozsudku.) Vnútroštátne súdy EÚ, predovšetkým nemecké ${ }^{48}$, v rozhodovacej praxi aplikujú rozhodnutie Súdneho dvora a rozhodujú o nadväzujúcich otázkach, ako napr. Musia na seba kroky opísané v rozsudku Huawei v ZTE striktne nadväzovat alebo je údajný porušitel' povinný predložit FRAND ponuku aj v prípade, ked' držitel' SEP neslnil vlastnú notifikačnú a ponukovú povinnost' tak, ako je opísaná v rozsudku Huawei $v$ ZTE ${ }^{49}$ Postačuje notifikácia materskej spoločnosti údajného porušitel'a práv z patentu? ${ }^{50}$ Ak držitel' SEP predloží celosvetovú licenčnú ponuku, môže údajný porušitel' predložit protiponuku obmedzenú na konkrétnu krajinu? ${ }^{51}$ Ak držitel' patentu nevyhnutného pre normu, ktorý prevzal FRAND záväzok, prevedie práva k SEP na iný subjekt, je nový držitel práv k SEP povinný poskytnút licenciu za FRAND podmienok? ${ }^{52}$

${ }^{48}$ Podla White \& Case LLP je Nemecko u vlastníkov patentov žiadané fórum na prejednanie európskych patentových sporov. Nemecké súdy boli „štedré“ v udel’ovaní predbežných opatrení v konaniach o porušenie práva duševného vlastníctva, nakol'ko mali za to, že námietky o zneužití dominantného postavenia nebránia vyhoveniu návrhu, a to ani pokial' išlo o spor týkajúci sa patentu nevyhnutného pre normu. (JAMES Killick. ECJ rips up Orange Book! New standards in Europe for SEP injunctions. [online] 2015. [cit. 30. 9. 2017] Dostupné na: https://www.whitecase.com/sites/whitecase/files/files/download/publications/ecj-rips-up-orange-book-27-july-2015.pdf ).

49 Rozhodnutie Oberlandesgericht Düsseldorf zo dňa 13. 1. 2016 vo veci Sisvel v Haier (15 $\mathrm{U} 65 / 15$ ).

${ }^{50}$ Rozhodnutie Landgericht Düsseldorf zo dňa 3. 11. 2015 vo veci Sisvel Wireless Patent Portfolio $v$ Qingdao Haier Group (4a O 93/14 and 4a O 144/14).

51 Rozhodnutie Landgericht Mannheim zo dňa 27. 11. 2015 vo veci Saint Lawrence Comms. GmbH v Deutsche Telekom (2 O 106/14).

52 Podla Európskej Komisie je dôležité, aby s prevodom práv k SEP prešli na nadobúdatela aj FRAND záväzky prevodcu. (EURÓPSKA KOMISIA: Tlačová správa zo dňa 10. 12. 2009. Commission Welcomes IPCom's Public FRAND Declaration' [online] 2009. [cit. 30. 9. 2017] Dostupné na http://europa.eu/rapid/ press-release_MEMO-09-549_en.htm 


\section{ZÁVER}

Stanovenie štandardu prináša výhody nielen výrobcom, ktorých produkty získajú lepšie postavenie na trhu, ale aj spotrebitel’om, ktorí majú väčší výber porovnatel'ných a vzájomne kompatibilných produktov. Bez stanovenia štandardov by si naše (nielen elektronické) zariadenia vyžadovali dodatočné konektory, pluginy, konvertory, čo by zvýšilo náklady na ich využívanie. Štandardy sú obzvlášt dôležité na trhu smarfónov, a to z dôvodu sietovej externality, ${ }^{53}$ pri ktorej hodnota zariadenia pre používatela stúpa s narastajúcim počtom používatel'ov daného (resp. kompatibilného) typu zariadenia. Každý nový používatel získava nielen benefit pre seba samého, ale aj pre ostatných používatel'ov.

Huawei $v$ ZTE je pragmatické rozhodnutie smerujúce $\mathrm{k}$ vyváženiu záujmov držitel'ov patentov nevyhnutných pre normu a subjektov, ktoré chránenú technológiu (nevyhnutnú pre dosiahnutie štandardu potvrdeného štandardizačnou organizáciou) implementujú. Súdny dvor sa výrazne odklonil od nemeckej patentee-friendly judikatúry, ${ }^{54}$ ktorá prevažne vyhovovala žalobám držitel’ov patentov, pretože používatel'ov zatažovala značným dôkazným bremenom. Museli preukázat, že predložili licenčnú ponuku, ktorú držitel' práv nemohol rozumne odmietnut a že zaplatili licenčné poplatky do zálohy. Rozsudok Huawei $v$ ZTE sa čiastočne odlíšil aj od user-friendly prístupu Európskej komisie v konaniach Samsung ${ }^{55}$ a Motorola ${ }^{56}$, v ktorých Komisia očakáva od vlastníka SEP, že bude proaktívny a formálne vyzve používatel'a k rokovaniu o odplate, pričom ochota používatela k uzatvoreniu licenčnej zmluvy sa prezumovala a dôkazné bremeno o opaku niesol vlastník SEP. Súdny dvor dodržiavajúc princíp non ultra peti-

53 PAGE, H. William \& LOPATKA, E. John. Network Externalities In Encyclopedia of Law \& Economics. 760, 952-980 [online] 1999. [cit. 30. 9. 2017] Dostupné na: http://reference.findlaw.com/lawandeconomics/0760-network-externalities.pdf

${ }^{54}$ Rozsudok Bundesgerichtshof zo dňa 6. 5. 2009 vo veci Orange Book Standard (KZR 39/06).

55 Rozhodnutie Európskej komisie zo dňa 29. 4. 2014 vo veci Samsung (Case AT.39939) [online] 2014. [cit. 30. 9. 2017] Dostupné na: http://ec.europa.eu/competition/antitrust/cases/ dec_docs/39939/39939_1501_5.pdf

56 Rozhodnutie Európskej komisie zo dňa 29. 4. 2014 vo veci Motorola. (Case AT.39985) [online] 2014. [cit. 30. 9. 2017] Dostupné na: http://ec.europa.eu/competition/antitrust/cases/dec_docs/39985/39985_928_16.pdf 
ta, neobjasnil vztah medzi vlastníctvom práv k SEP a dominantným postavením na trhu, ${ }^{57}$ ani sa bližšie nezaoberal určitel'nostou FRAND záväzku.

Pokial' ide o vztaah medzi právom duševného vlastníctva a hospodárskej sútaže, v súčasnosti prevláda názor, že právo duševného vlastníctva a jeho vplyv na trhovú sútaž majú byt’ vo všeobecnosti akceptované, čo však neznamená, že výkon týchto práv nepodlieha kontrole sútažného práva. ${ }^{58}$ Iniciovanie zdržovacej žaloby majitel’om patentu nemôže samo osebe predstavovat’ zneužitie dominantného postavenia. Výkon práv duševného vlastníctva narúša hospodársku sútaž iba za osobitných okolností.

Rozsudok Huawei $v$ ZTE nadväzuje na teóriu osobitných okolností, ktorá bola použitá pri posúdení, či je odmietnutie poskytnutia licencie v súlade s článkom 102 ZFEÚ v rozhodnutiach Magill a IMS Health. Uvedenú doktrínu Súdny dvor v Huawei v ZTE výkladom mení (napr. sa nezoberá podmienkou vytvorenia nového produktu) a upravuje pre prípad patentov nevyhnutných pre normu, ktorých status bol podmienený FRAND vyhlásením.

\section{ZOZNAM POUŽITÝCH ZDROJOV}

\subsection{LITERATÚRA}

[1] AHLBORN, Christian, EVANS, S. David a PADILLA, A. Jorge. The Logic \& Limits of the "Exceptional Circumstances Test" in Magill and IMS Health. In: Fordham International Law Journal. 2004, Vol. 28. 1109-1156 s.

[2] CZAPRACKA, Katarzyna. Intellectual property and the limits of antitrust: a comparative study of US and EU approaches. Cheltenham: Edward Elgar, 2009, 168 s. ISBN 9781847209252.

[3] KUR, Annette \& DREIER, Thomas. European intellectual property law: text, cases and materials. Cheltenham: Edward Elgar Publishing, 2013, 592 s. ISBN 9781848448797.

[4] LUNDQVIST, Björn. Standardization under EU Competition Rules and US Antitrust Laws: The Rise and Limits of Self-Regulation. Cheltenham: Edward Elgar Publishing. 2014, 496 s. ISBN 9781781954850 .

57 Pri určovaní dominancie sa vychádza z definície relevantného trhu, podielu podnikatela na tomto relevantnom trhu, jeho vývoja, zohl’adňujú sa však aj d’alšie faktory ako štruktúra trhu, bariéry vstupu na trh a vyrovnávacia kúpna sila.

58 KUR, Annette \& DREIER, Thomas. European intellectual property law: text, cases and materials. Cheltenham: Edward Elgar Publishing, 2013. ISBN 9781848448797. s 393. 
[5] PETIT, Nicolas. EU Competition Law Analysis of FRAND Disputes in The Cambridge Handbook of Technical Standardization Law, Jorge L. Contreras, ed., Cambridge University Press, Forthcoming 2017.

[6] STAMATOUDI, A. Irini. Copyright and multimedia products: a comparative analysis. Cambridge: Cambridge University Press, 2002, 335 s. ISBN 0521808197.

\subsection{PRÁVNE PREDPISY}

[7] Smernica Európskeho parlamentu a Rady 2004/48/ES z 29. 4. 2004 o vymožitelnosti práv duševného vlastníctva (Ú. v. EÚ L 157, s. 45; Mim. vyd. 17/002, s. 32).

\subsection{JUDIKATÚRA}

[8] Rozsudok Súdneho dvora Európskych spoločenstiev zo dňa 6. 4. 1995 vo veci Radio Telefis Eireann (RTE) a Independent Television Publications Ltd (ITP) $v$ Commission of the European Communities. (spojené konania C-241/91 P and C-242/91 P).

[9] Rozsudok Súdneho dvora Európskych spoločenstiev zo dňa 29. 4. 2004 vo veci IMS Health GmbH \& Co. OHG. (C-418/01).

[10] Rozsudok Všeobecného súdu (druhá komora) z 27. 6. 2012 vo veci Microsoft Corp. proti Európskej komisii. (T-167/08). ECLI:EU:T:2012:323.

[11] Rozsudok US District Court Western District of Washington at Seattle zo dňa 25. 4. 2013 vo veci Microsoft Corp. $v$ Motorola, Inc. (C10-1823JLR).

[12] Rozsudok High Court of Justice zo dňa 5. 4. 2017 vo veci Unwired Planet International Ltd v Huawei Technologies Co. Ltd and Huawei Technologies (UK) Co. Ltd (EWHC 711 (Pat).

[13] Rozsudok Súdneho dvora (piata komora) zo 16. 7. 2015 vo veci Huawei Technologies Co. Ltd/ZTE Corp., ZTE Deutschland GmbH. (C-170/13). ECLI:EU:C:2015:477.

[14] Rozhodnutie Oberlandesgericht Düsseldorf zo dňa 13. 1. 2016 vo veci Sisvel v Haier (15 U 65/15).

[15] Rozhodnutie Landgericht Düsseldorf zo dňa 3. 11. 2015 vo veci Sisvel Wireless Patent Portfolio $v$ Qingdao Haier Group (4a O 93/14 and 4a O 144/14).

[16] Rozhodnutie Landgericht Mannheim zo dňa 27. 11. 2015 vo veci Saint Lawrence Comms. GmbH v Deutsche Telekom (2 O 106/14).

[17] Rozsudok Bundesgerichtshof zo dňa 6. 5. 2009 vo veci Orange Book Standard. (KZR 39/06).

[18] Rozhodnutie 2007/53/ES, ktoré sa vztahuje na konanie podla článku 82 [ES] a článku 54 Dohody o EHP vedené proti spoločnosti Microsoft Corp. (COMP/C-3/37.792 - Microsoft) (Ú. v. EÚ L 32, 2007, s. 23). 


\subsection{ELEKTRONICKÉ ZDROJE}

[19] BROOKS Roger G. \& GERADIN Damien. Taking Contracts Seriously: The Meaning of the Voluntary Commitment to Licence Essential Patents on "Fair and Reasonable" Terms. [online] 2010. [cit. 30. 9. 2017] Dostupné na: https://www.cravath.com/files/Uploads/Documents/Publications/3233990_1.pdf

[20] BROWN-SANFORD Christa \& FORD R. Bethany. Post-Huawei FRAND Licensing of Standards-Essential Patents. [online] 2017. [cit. 30. 9. 2017] Dostupné na: http://www.bakerbotts.com/ideas/publications/2016/06/ip-report-post-huawei-frand-licensing

[21] EUROPEAN TELECOMMUNICATIONS STANDARDS INSTITUTE: ETSI Intellectual Property Rights Policy. [online] 2017. [cit. 30. 9. 2017] Dostupné na http://www.etsi.org/images/files/IPR/etsi-ipr-policy.pdf

[22] EURÓPSKA KOMISIA: Správa o politike hospodárskej sútaže za rok 2008. [online] 2009. [cit. 30. 9. 2017] Dostupné na: http://europa.eu/rapid/press-release_IP-09-1241_sk.pdf

[23] EURÓPSKA KOMISIA: DG Competition discussion paper on the application of Article 82 of the Treaty to exclusionary abuses. [online] 2005. [cit. 30. 9. 2017] Dostupné na: http://ec.europa.eu/competition/antitrust/art82/discpaper2005.pdf

[24] EURÓPSKA KOMISIA: Tlačová správa zo dňa 21. 12. 2012: Antitrust: Commission sends Statement of Objections to Samsung on potential misuse of mobile phone standard-essential patents. [online] 2012. [cit. 30. 9. 2017] Dostupné na: http://europa.eu/rapid/press-release_IP-121448_en.htm

[25] EURÓPSKA KOMISIA: Tlačová správa zo dňa 29. 4. 2014: Antitrust: Commission accepts legally binding commitments by Samsung Electronics on standard essential patent injunctions. [online] 2014. [cit. 30. 9. 2017] Dostupné na: http://europa.eu/rapid/press-release_IP-14490_en.htm

[26] EURÓPSKA KOMISIA: Tlačová správa zo dňa 10. 12. 2009. Commission Welcomes IPCom's Public FRAND Declaration' [online] 2009. [cit. 30. 9. 2017] Dostupné na http://europa.eu/rapid/ press-release_MEMO-09-549_en.htm

[27] EURÓPSKA KOMISIA: Rozhodnutie zo dňa 29. 4. 2014 vo veci Samsung (Case AT.39939) [online] 2014. [cit. 30. 9. 2017] Dostupné na: http://ec.europa.eu/competition/antitrust/cases/dec_docs/39939/39939_1501_5.pdf

[28] EURÓPSKA KOMISIA: Rozhodnutie zo dňa 29. 4. 2014 vo veci Motorola (Case AT.39985) [online] 2014. [cit. 30. 9. 2017] Dostupné na: http://ec.europa.eu/competition/antitrust/cases/dec_docs/39985/39985_928_16.pdf

[29] JAMES Killick. ECJ rips up Orange Book! New standards in Europe for SEP injunctions. [online] 2015. [cit. 30. 9. 2017] nostupné https://www.whitecase.com/sites/whitecase/files/files/download/publications/ecj-rips-uporange-book-27-july-2015.pdf 
[30] MAUME, Philipp. Huawei ./. ZTE, or, how the CJEU closed the Orange Book. In: Queen Mary Journal of Intellectual Property. Online ISSN 20459815 [online] 2016. [cit. 30. 9. 2017] Dostupné na: https://www.elgaronline.com/view/journals/ qmjip/6-2/qmjip.2016.02.04.xml

[31] PAGE, H. William \& LOPATKA, E. John. Network Externalities In: Encyclopedia of Law \& Economics. 760, 952-980 [online] 1999. [cit. 30. 9. 2017] Dostupné na: http://reference.findlaw.com/lawandeconomics/0760-network-externalities.pdf

[32] THE MAX PLANCK INSTITUTE FOR INTELLECTUAL PROPERTY, COMPETITION AND TAX LAW: Comments of the Max Planck Institute for Intellectual Property, Competition and Tax Law (Munich) on the DG Competition discussion paper of December 2005 on the application of Article 82 of the EC Treaty to exclusionary abuses [online] 2006. [cit. 30. 9. 2017] Dostupné na: http://ec.europa.eu/ competition/antitrust/art82/047.pdf

Toto dílo lze užít v souladu s licenčními podmínkami Creative Commons BY-SA 4.0 International (http://creativecommons.org/licenses/by-sa/4.0/legalcode). 